Disponível em

http://www.anpad.org.br/rac

RAC, Rio de Janeiro, v. 19, n. 4, art. 2, pp. 440-460, Jul./Ago. 2015

http://dx.doi.org/10.1590/1982-7849rac20151377

$($ (c) EY-No

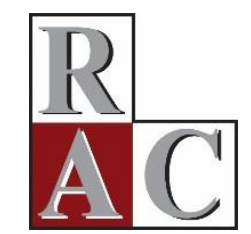

\title{
Abordagem Conceitual às Estratégias de Internacionalização sob Pressões Institucionais Duais para Legitimidade e Conformidade
}

A Conceptual View of Internationalization Strategies under Dual Institutional Pressures for Legitimacy and Conformity

Manuel Portugal Ferreira Universidade Nove de Julho - UNINOVE; Instituto Politécnico de Leiria - ESTG

Fernando Ribeiro Serra Universidade Nove de Julho - UNINOVE

Artigo recebido em 23.03.2013. Última versão recebida em 18.10.2014. Aprovado em 20.10.2014. 


\title{
Resumo
}

Internacionalizar as operações requer que as empresas multinacionais (EMNs) desenvolvam estratégias capazes de lidar, simultaneamente, com as pressões institucionais externas, para a legitimidade, e as pressões institucionais internas, para a conformidade. Neste artigo conceitual e baseado na literatura de teoria institucional em negócios internacionais, desenvolve-se um conjunto de proposições teóricas sobre quais as estratégias de entrada nos mercados externos seguidas pelas EMNs face aos ambientes institucionais. Com foco predominante no ambiente institucional externo e nas diferenças de desenvolvimento institucional, também aborda a relevância de considerar o ambiente interno. As estratégias de entrada tendem a ser baseadas em modos de baixo envolvimento e em parcerias, como joint ventures, para entrar em países institucionalmente imaturos ou institucionalmente mais distantes. As aquisições e as parcerias podem ser usadas se as pressões institucionais forem menores. Conclui-se com uma discussão geral e o apontamento de questões para pesquisas futuras.

Palavras-chave: modos de entrada; estratégia de internacionalização; adaptação; ambiente institucional.

\begin{abstract}
Internationalizing operations requires multinational corporations (MNCs) to develop strategies capable of simultaneously dealing with external institutional pressures towards legitimacy and internal institutional pressures towards conformity. In this conceptual paper we develop a set of theory-driven propositions on what are the internationalization strategies that MNCs must deploy given their institutional environments. Especially emphasizing the external institutional environment and differences in institutional development, we also approach the relevance of considering the internal institutional environment to the firm. Entry strategies tend to be based on low-involvement modes and on partnerships, such as joint-ventures, to enter institutionally immature or institutionally farther countries. Acquisitions and partnerships may be used when internal institutional pressures are weaker. We conclude with a broad discussion and avenues for future research.
\end{abstract}

Key words: entry modes; internationalization strategies; adaptation; institutional environment 


\section{Introdução}

Na literatura sobre negócios internacionais, a explicação de como as empresas multinacionais (EMNs) selecionam as suas estratégias de internacionalização e, especificamente, as de entrada nos mercados externos tem sido baseada nas imperfeições de mercado e nos custos de transação (Buckley \& Casson, 1976; Hennart, 1982; Williamson, 1985). Ênfase mais recente tem tido os fatores específicos à empresa no enquandramento conceitual da Visão Baseada em Recursos (VBR) (Anand \& Delios, 2002; Barney, 1991) e a importância das redes de relacionamento (Chen \& Chen, 1998; Dunning, 1995; M. P. Ferreira, Li, Serra, \& Armagan, 2008). Essas teorias, no entanto, podem não ser suficientes para capturar a complexidade de todos os aspectos relevantes na escolha do modo de entrada na internacionalização, pelo que, neste estudo, focaliza-se uma explicação conceitual complementar: a teoria institucional. $\mathrm{O}$ modo como as empresas internacionalizam-se não é independente nem de fatores internos à própria empresa nem do ambiente institucional dos países receptores (D. Li, Miller, \& Eden, 2012; K. Meyer \& Peng, 2005; M. P. Ferreira, Li, \& Jang, 2009).

Guisinger (2001) sugeriu que a essência da pesquisa em negócios internacionais é a adaptação que as empresas precisam fazer quando enfrentam ambientes que desconhecem nos países estrangeiros. Os desafios de adaptação emergem pelo desconhecimento das normas e regulações locais, falta de legitimidade no país receptor, instituições fracas ou ineficazes (Hymer, 1976; Wright, Filatotchev, Hoskisson, \& Peng, 2005), indiciando que o ambiente institucional do país receptor molda as estratégias de entrada. Assim, aumentam os custos de transação que emergem de operar em ambientes distintos e desconhecidos pela empresa (Kostova, Roth, \& Dacin, 2008; North, 1990). Esses custos têm origem na majoração das barreiras de comportamentos oportunísticos, dificuldades de contratação e racionalidade limitada dos agentes, diferenças culturais, legais e regulatórias, entre outras, que aumentam os custos das operações (K. Meyer, Estrin, Bhaymik, \& Peng, 2009).

Para se adaptarem aos países receptores, as EMNs necessitam responder eficazmente às pressões institucionais externas, mas também às internas (DiMaggio \& Powell, 1983; Kostova \& Roth, 2002; Scott, 2003) que existem no seio das multinacionais e entre subsidiárias integradas. Essas são, segundo Henisz (2000), ações mitigadoras dos riscos. Então, a escolha das estratégias de entrada nos mercados externos deve ser usada como uma opção estratégica capaz de equilibrar as pressões internas para a conformidade com as pressões externas de legitimidade.

A literatura acadêmica distingue esses dois tipos de pressões institucionais: externas e internas. As externas incluem as estruturas reguladoras, as agências governamentais, a opinião pública, leis e sistema legal, tribunais, grupos de interesse, profissões, cultura, regulação e economia (Scott, 2003). Ou seja, cada nova subsidiária é pressionada para ganhar legitimidade no país receptor, adotando um conjunto de normas, regras, procedimentos e relacionamentos, valores e estrutura organizacional que sejam ajustados aos requisitos institucionais dos locais (Lu, 2002; Martin, Swaminathan, \& Mitchell, 1998). As pressões internas, em contraponto, evidenciam que cada subsidiária no estrangeiro precisa assumir normas, valores, práticas e procedimentos, esquemas e modelos organizacionais, etc., que estejam em conformidade com as normas internas da EMN (Davis, Desai, \& Francis, 2000; Kostova \& Roth, 2002; M. P. Ferreira et al., 2009). Esse é um processo de isomorfismo, em que cada subsidiária necessita ser suficientemente semelhante às outras subsidiárias da EMN para ser considerada como um membro do grupo que é a EMN (Henisz \& Delios, 2001). Como Oliver (1997, p. 697) notou: "o ambiente institucional das empresas inclui a sua cultura interna e as influências mais gerais que o estado, a sociedade e as relações inter-empresas que definem os comportamentos econômicos socialmente aceitáveis".

Neste artigo, desenvolve-se sobre a teoria institucional para analisar conceitualmente as opções estratégicas das EMNs para a entrada nos mercados estrangeiros, face ao impacto das múltiplas facetas do ambiente institucional interno e externo. A proposta-base é que a escolha do modo de entrada das EMNs é estratégica e pondera dois tipos de pressões institucionais potencialmente antagônicas: as pressões externas, que levam as EMNs a procurar legitimidade no país receptor, e as internas às próprias 
EMNs, que se refletem na tensão para que cada subsidiária seja conforme as restantes da EMN. Especificamente, desenvolvem-se proposições teóricas sobre o ambiente institucional no país receptor, distância institucional entre país de origem e receptor e ambiente interno das EMNs.

Este estudo contribui para a literatura sobre modos de entrada no estrangeiro, em especial quando envolve a entrada em mercados diferentes ou desconhecidos, examinando que as empresas podem fazer escolhas estratégicas que são respostas às condições ambientais externas (ver Haunschild \& Miner, 1997; Henisz, 2000; Oliver, 1991). Outra contribuição é para a promoção de uma perspectiva que integre a atenção ao contexto social, no qual a seleção dos modos de entrada está imersa (embedded), em condições de incerteza (DiMaggio \& Powell, 1983; Granovetter, 1985), e estabelece uma base conceitual para futuros estudos empíricos. Revela-se, assim, como as dinâmicas sociais podem se sobrepor aos argumentos de racionalidade econômica preconizados na literatura de modos de entrada. Assim, ainda que numa abordagem conceitual e sem testes empíricos, contribui inclusive para entender como uma perspectiva institucional sobre as decisões de modo de entrada permite aprofundar o debate contrastando explicações econômicas e sociais.

\section{Ambiente Institucional e as EMNs}

Instituições de qualidade são vitais ao funcionamento da economia, pois permitem que indivíduos e empresas possam recorrer aos mecanismos de mercado sem incorrerem em ineficiências e elevados custos de transação (North, 1990; Scott, 2003; Williamson, 1985). Em países institucionalmente desenvolvidos, ou seja, aqueles onde as instituições são fortes e eficientes, a contratação no mercado (por oposição à internalização) não traz riscos e/ou custos adicionais. As instituições incluem o sistema legal, os direitos de propriedade física e intangível, os sistemas de regulação, agências de diferentes propósitos, tribunais, profissões, grupos de interesse e opinião pública (Oliver, 1991; Scott, 2003).

As EMNs são particularmente expostas às diferenças institucionais entre os países onde operam (Henisz \& Delios, 2001; Kostova et al., 2008; Martin et al., 1998). Instituições fracas elevam os custos das operações, os riscos de ter parcerias nesses países, os custos para coletar informação sobre potenciais parceiros (D. Li \& Ferreira, 2011; Kostova et al., 2008). As dificuldades de operar podem emergir de diferenças nos sistemas formais (como leis e regulamentações) ou entre o leque de regras formais e informais que efetivamente vigoram. K. Meyer, Estrin, Bhaymik, \& Peng (2009) dão o seguinte exemplo: num país, o sistema institucional legal pode não impor barreiras à posse de uma empresa por capital estrangeiro - o que favoreceria, ceteris paribus, que a EMN detivesse $100 \%$ do capital de uma empresa no país receptor; mas as normas informais de corrupção e subornos ou os laços informais para obter um contrato podem favorecer a parceria com empresas locais bem-estabelecidas e com uma ampla network de contatos.

Para serem aceitas, as EMNS precisam construir legitimidade no país receptor, pelo que experimentarão a pressão para adaptar as suas práticas ao contexto institucional local (Kostova \& Roth, 2002). Isso significa respeitar e adotar as regras formais e informais, normas, comportamentos e cerimônias que são considerados apropriados (DiMaggio \& Powell, 1983; Gomes \& Gomes, 2007; J. Meyer \& Rowan, 1977; Kostova \& Zaheer, 1999; Oliver, 1991). Ou seja, para sobreviver e prosperar, as empresas necessitam ganhar legitimidade, que conseguem por meio de comportamento isomórfico (D. Li et al., 2012; DiMaggio \& Powell, 1983; Haunschild \& Miner, 1997; J. Meyer \& Rowan, 1977; Lu, 2002; Martin et al., 1998). Em essência, isso significa imitar os agentes locais, utilizando as práticas institucionalizadas (Haveman, 1993). A imitação é, assim, uma escolha estratégica que visa aumentar a legitimidade (D. Li et al., 2012; DiMaggio \& Powell, 1983; J. Meyer \& Rowan, 1977; Haveman, 1993; Haunschild \& Miner, 1997; Henisz \& Delios, 2001). Como propõem DiMaggio e Powell (1983) e D. Li et al. (2012), em condições de incerteza, as normas sociais e os compromissos tidos como garantidos (taken-for-granted) sobre o que constitui um comportamento econômico socialmente aceitável nos mercados receptores (DiMaggio \& Powell, 1983; Oliver, 1997; Zukin \& DiMaggio, 1990) podem 
prevalecer sobre critérios de eficiência e técnicos, e as regras institucionais, suplantar as normas técnicas.

Embora o ambiente institucional seja crucial, Oliver $(1991,1997)$ foi pioneiro em afirmar que nem as pressões institucionais são determinísticas nem as empresas são prisioneiras de um isomorfismo determinístico (ver D. Li et al., 2012). Se fossem, não haveria variação substancial entre empresas e todas assumiriam formas, práticas e estratégias idênticas. Por meio de suas estratégias, incluindo as de internacionalização, as empresas respondem ao ambiente, mudam-no ou influenciam-no (Oliver, 1991). As escolhas de estratégia internacional e dos países para onde se internacionalizam são, então, uma resposta estratégica às pressões institucionais (Henisz, 2000). A respeito da escolha dos mercados externos, Westney (1993) notou que as multinacionais de automóveis japonesas preferem investir em regiões nos EUA onde a institucionalização da indústria norte-americana de automóvel é fraca ou não existente. Nessas regiões, há menores níveis de sindicalização e um grande número de desempregados receptivos a aprender novas práticas, procedimentos, modos de organização do trabalho, etc. - ou seja, onde as empresas japonesas podem impor a sua forma de trabalhar. Em suma, ao buscar a legitimidade local, as EMNs reduzem os potenciais impactos negativos de serem estrangeiras (ver o conceito de liability of foreigness) (Hymer, 1976), adotando ações mitigadoras dos riscos e custos.

As EMNs têm outra preocupação, dado que crescentemente são concebidas como uma rede integrada, em que cada subsidiária tem um papel distinto (Bartlett \& Ghoshal, 1989; Boehe \& Zawislak, 2007). Refere-se às pressões internas que induzem cada subsidiária a manter-se semelhante, ou isomórfica, a outras subsidiárias, em práticas variadas, incluindo os modos de entrada adotados, os procedimentos e rotinas, a contratação de expatriados, as parcerias com agentes financiadores, etc. Isto é, as pressões internas se suportam num conjunto amplo de premissas, regras, rotinas, procedimentos que imanam internamente e que todas as subsidiárias adotam ou se espera que adotem (Kostova, 1999).

Em resumo, na seleção dos modos de entrada, a EMN depara-se com duas pressões, potencialmente conflitantes, uma para a legitimidade externa - que se manifesta na necessidade de adaptação aos requisitos locais - e outra para a conformidade interna - que se manifesta na adaptação às normas internas da EMN (DiMaggio \& Powell, 1983; Kostova \& Roth, 2002). É essa a dualidade institucional - uma específica a cada país e outra específica à rede interna da empresa multinacional.

A pesquisa existente tem sido prolífica na análise dos benefícios e desvantagens dos diferentes modos de entrada (ver Dias, Rocha, \& Silva, 2014; Root, 1994). Os principais modos de entrada são: exportação, contratos (como os de licenciamento), alianças estratégicas, joint ventures, aquisições internacionais (envolvendo parte ou a totalidade do capital da empresa adquirida) e investimentos de raiz (ou greenfield). Os modos de entrada de menor compromisso, ou seja, que não envolvem investimento, são de menor risco, pois protegem melhor a EMN face a riscos do país receptor e das transações (Root, 1994). Assim, tendem a ser escolhidos como forma de ultrapassar a inexperiência internacional, o desconhecimento de certos países externos (Davis et al., 2000; D. Li et al., 2012) e debilidades institucionais locais (Peng \& Heath, 1996).

Os modos de entrada baseados em investimento direto, em contraponto, incorporam maiores riscos, mas podem permitir a aprendizagem local ou o acesso aos conhecimentos de um parceiro (Boehe \& Zawislak, 2007; M. P. Ferreira, 2008). As aquisições, especificamente, têm a vantagem de concederem imersão imediata no ambiente institucional local e permitirem à empresa entrar em redes de relações já estabelecidas no país receptor. As joint ventures podem permitir usar o parceiro para adquirir conhecimento do mercado local, bem como aceder aos seus laços sociais e de negócios. Finalmente, a entrada através de investimentos greenfield é uma estratégia baseada no controle total das subsidiárias estrangeiras, mas tem a desvantagem de impor um grau de foreignness mais alto no país receptor. Ou seja, é uma estratégia que resulta em menor adaptação ao país receptor, ainda que possa proteger melhor vantagens específicas à empresa (M. P. Ferreira, 2008) e garantir conformidade interna. 


\section{Adaptação Estratégica às Várias Facetas dos Ambientes Institucionais}

Apesar da abundância de estudos sobre as estratégias de entrada das EMNs no exterior, é escassa a pesquisa que reúne fatores econômicos e contextos sociais (D. Li \& Ferreira, 2011; K. Meyer \& Peng, 2005; K. Meyer et al., 2009; M. P. Ferreira et al., 2008). Na Figura 1, ilustram-se as diferentes facetas dos ambientes institucionais e o seu impacto nas escolhas dos modos de entrada. Não é objetivo deste artigo examinar todo o leque possível de escolhas estratégicas, mas apenas formular um conjunto de proposições ilustrativas da racionalidade a adotar-se na análise das estratégias de entrada.
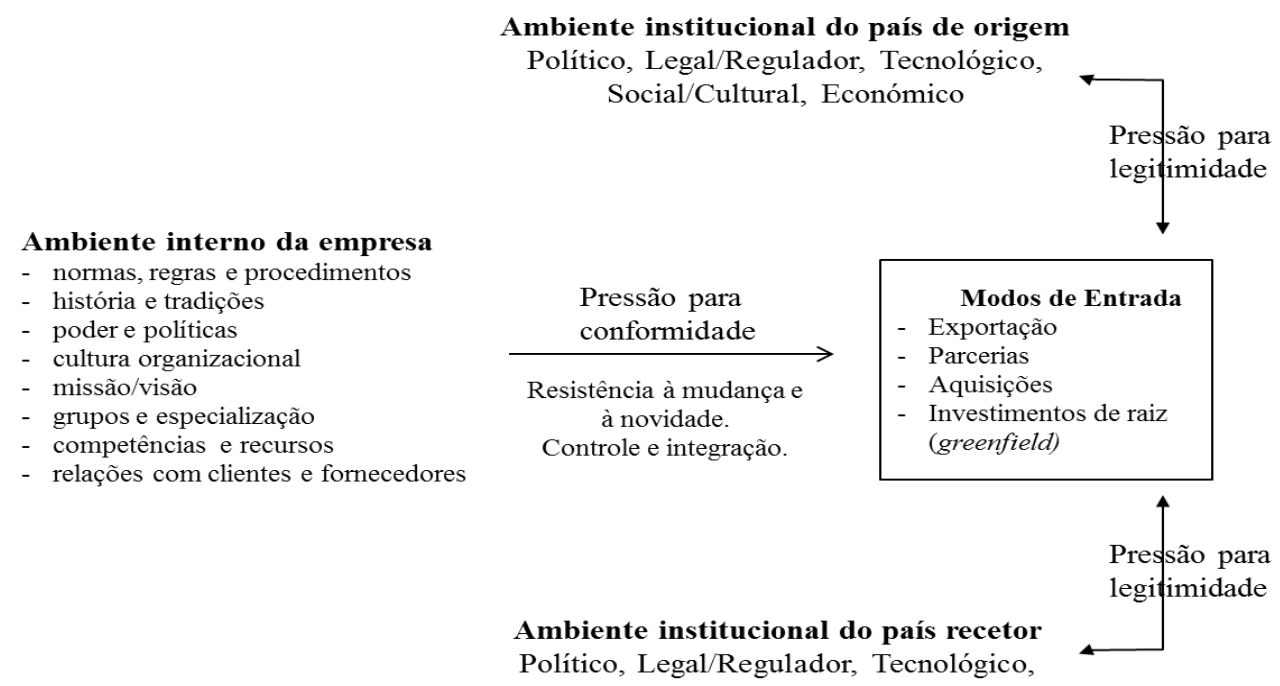

Social/Cultural, Económico

Figura 1. Modelo Geral da Interação entre a EMN e o Ambiente Institucional Fonte: Elaborada pelos autores.

A Figura 1 revela uma concepção ampla do ambiente institucional. Enquanto a pesquisa existente tem focado especialmente nas instituições influenciadas pelo governo, em aspectos tais como a instabilidade ou risco político, leis, eficiências das agências públicas e da banca (D. Li \& Ferreira, 2011; Henisz, 2000; K. Meyer \& Peng, 2005; Wright et al., 2005), inclui-se um leque mais abrangente de fatores quer do país de origem quer do país receptor. Observa-se, assim, nos topos da figura, as dimensões externas: social, cultural, política, legal/regulatória, econômica e tecnológica. A figura inclui, também, as pressões internas - como normas, valores, relações de poder, cultura organizacional, história e percursos prévios, tradições, recursos da empresa - pela sua influência nas escolhas estratégicas para a entrada em países estrangeiros. Ou seja, na figura revelam-se as pressões internas para a conformidade e as pressões externas (de país de origem e receptor) para a legitimidade.

Dado que as EMNs estão imersas num sistema de pressões econômicas e institucionais interrelacionadas, não é provável que uma dessas pressões domine as restantes, determinando as escolhas estratégicas das EMNs (Dacin, 1997; Granovetter, 1985). Antes, as escolhas estratégicas dependerão do conjunto das pressões institucionais, que variam entre países, e dos objetivos estratégicos da empresa para cada um dos mercados externos.

\section{O ambiente institucional do país receptor}

As características do ambiente institucional do país receptor influenciam as estratégias de entrada das EMNs (Scherer, Gomes, \& Kruglianskas, 2009). O ambiente institucional do país receptor é composto de regras, normas e tradições, algumas das quais são explícitas, enquanto outras não (J. Meyer \& Rowan, 1977). Num ambiente institucional bem-desenvolvido, as sanções coletivas exercidas por quem viola as normas são severas, porque as normas são amplamente aceitas e há instituições eficazes que ou previnem as violações às normas ou impõem coercivamente o respeito pelas normas 
prevalecentes (Henisz, 2000). Essas instituições são necessárias para, por exemplo, formar com sucesso alianças estratégicas e joint ventures ou para realizar contratos.

Em países com um sistema institucional bem-desenvolvido, os custos de transação de realizar negócios são baixos (Bevan, Estrin, \& Meyer, 2004; D. Li \& Ferreira, 2011; K. Meyer, 2001; K. Meyer et al., 2009; M. P. Ferreira et al., 2008; Peng, 2003). Henisz (2000) e K. Meyer (2001) notaram como o sistema institucional influencia os custos relativos de cada modo de entrada. Por exemplo, países receptores institucionalmente desenvolvidos garantem o respeito pelos contratos, pela propriedade privada e intelectual e mantêm baixos os custos de transação e os comportamentos oportunísticos (Henisz, 2000; K. Meyer, 2001; Williamson, 1985). Nesses casos, a EMN será mais propensa a preferir modos de entrada que envolvam a colaboração com outras empresas - por exemplo, usando alianças estratégicas ou contratos.

Em ambientes institucionais desenvolvidos, a EMN pode não ter o incentivo para realizar internamente as atividades, pelo que a opção pelo investimento de raiz, pelo menos em subsidiárias detidas a $100 \%$, possivelmente, não será a primeira opção. De fato, nesses ambientes, dados os baixos custos de transação, os objetivos comerciais e de aprendizagem podem ser atingidos de duas formas: encontrando um parceiro local (por meio de uma joint venture ou aquisição parcial) ou adquirindo a totalidade de uma empresa local já estabelecida e integrada na estrutura social local. Ambos os modos - parcerias e aquisições - garantem legitimidade com o ambiente institucional receptor. As parcerias, como as joint ventures, proporcionam às empresas o acesso a um conjunto alargado de recursos do parceiro, incluindo os seus recursos técnicos e humanos, mas também os sociais e as suas redes relacionais, que ajudam a ultrapassar as dificuldades sentidas de operar em mercados institucionalmente mais fracos (D. Li \& Ferreira, 2011; Delios \& Beamish, 1999; Dikova \& Witteloostuijn, 2007). Em contraste, o objetivo de legitimidade local é menos conseguido com exportação e investimentos de raiz porque ambos envolvem trazer algo de estrangeiro para o mercado local. Essa afirmativa é interessante para acadêmicos de negócios internacionais porque contrasta com a perspectiva de que as parcerias são modelos interorganizacionais para a partilha de riscos associados a países instáveis e com alto risco (Henisz, 2000). No entanto é consistente com o aumento do número de alianças estratégicas nos países ocidentais (Dunning, 1995), que têm sistemas institucionais mais previsíveis e estabelecidos que países economicamente menos desenvolvidos. Assim, parece razoável sugerir que as EMNs tenderão a escolher estratégias colaborativas para novas entradas quando o país receptor tem um ambiente institucional mais desenvolvido. Um exemplo seria a possibilidade de retorno da FIAT aos EUA, em 2012, trinta anos depois de deixar o país, com a aquisição parcial da Chrysler (The Economist, 2010). No setor bancário brasileiro, Nunes, Serra e Ferreira (2011) observaram como a expansão para a Europa ocorre com parcerias. Com essa solução, as empresas evitam dispender recursos humanos e financeiros e não incorrem nos riscos de comportamentos oportunísticos ou de dissipação das suas vantagens baseadas em conhecimento.

Proposição 1. EMNs entrando em países com um sistema institucional bem-estabelecido mais provavelmente usarão estratégias de entrada baseadas em parcerias, em oposição a estratégias de entrada por exportação ou investimentos de raiz.

Uma argumentação diferente da proposição 1 pode ser delineada. A necessidade de ter parceiros pode diminuir com o maior grau de desenvolvimento institucional (K. Meyer, 2001; Peng, 2003). Por exemplo, a pesquisa em economias emergentes mostra que, quando o ambiente regulatório melhora, há mais setores de atividade econômica que se abrem aos capitais estrangeiros (Andrade \& Galina, 2013; Cuervo-Cazurra, 2008; Peng \& Heath, 1996). Essa abertura é possível porque a própria regulamentação e formalismos se tornam mais simples, mais claros e transparentes, requerendo menos licenças, alvarás e burocracia. Ou seja, a melhoria institucional que reduz as barreiras ao investimento estrangeiro também reduz a necessidade de ter um parceiro local para servir de interface com os agentes políticos e econômicos (Bevan et al., 2004; D. Li \& Ferreira, 2011; K. Meyer, 2001).

Quando, em 1991, a Marcopolo instalou a primeira fábrica da empresa no exterior, tinha por objetivo aprender novas tecnologias porque a de ônibus estava mais avançada na Europa. Assim, também conseguia estar mais próxima dos fabricantes europeus com os quais podia aprender (Macadar, 
2009). Nesse caso, o maior desenvolvimento institucional do país receptor não requeria parcerias e a Marcopolo optou por um investimento de raiz. Também a expansão da CVRD para o Canadá, em 2006, pôde ser por meio de aquisição da INCO (Macadar, 2009), dado que os riscos e incertezas institucionais externos eram baixos e o Canadá estava num nível de desenvolvimento institucional superior ao Brasil. De modo similar, foi a expansão, em 1999, da Gerdau para os Estados Unidos com a aquisição do controle da Ameristeel.

Observando as aquisições de empresas, pode-se razoavelmente propor que as aquisições são muito sensíveis ao grau de desenvolvimento institucional dos países receptores. A realização de aquisições depende da sofisticação e eficiência do mercado de capitais para financiamento, e os próprios custos de transação envolvidos dependem da transparência do mercado e da eficácia legislativa (D. Li \& Ferreira, 2011; Peng \& Heath, 1996). Assim, formula-se a seguinte proposição alternativa:

Proposição 1a. EMNs entrando em países com um sistema institucional bem-estabelecido mais provavelmente usarão estratégias de investimento de raiz ou aquisições totais.

\section{Decompondo o ambiente institucional do país receptor}

O ambiente institucional do país receptor pode ser analisado decompondo-o em três dimensões: normativa, cognitiva e regulatória (D. Li \& Ferreira, 2011; Scott, 2003; Xu \& Shenkar, 2002). Partindo dessas três dimensões, pode-se analisar como influenciam diferenciadamente a estratégia de internacionalização. Os aspectos regulatórios incluem as regras e regulamentações que, sendo explicitamente articuladas, podem ser observadas e seguidas. Assim, para a EMN, é relativamente transparente saber como ganhar legitimidade quando o sistema institucional regulatório é desenvolvido. As economias emergentes, e em transição, tendem a ter ambientes regulatórios relativamente incipientes e ineficazes, pelo que menos transparentes e de mais difícil atuação (Cuervo-Cazurra, 2008; Peng, Wang, \& Jiang, 2008).

Ao contrário do ambiente regulatório, os aspectos normativo e cognitivo do ambiente institucional são consideravelmente menos perceptíveis para as EMNs estrangeiras, pelo que a adaptação a eles será mais difícil. Por exemplo, compreender as normas cognitivas e as idiossincrasias culturais nos negócios e nas interações pessoais é fundamental nos países asiáticos e latinos (Peng et al., 2008). Nesses países, as normas informais de oferecer presentes, as hierarquias, a distância pessoal e o que entra na esfera pública e privada, além de todas as tradições, são de difícil compreensão para empresas estrangeiras. Um exemplo claro encontra-se no sul da Itália, onde a tradição dos homens de honra e as interações sociais entre as famílias são normas complexas que estão na base da estrutura social, e elas são difíceis de entender para empresas estrangeiras.

As normas informais não estão escritas, são tácitas e contrastam com as normas formais, impostas por sistemas legais e judiciais (Scott, 2003). O fato é que uma violação de normas cognitivas ou normativas pode constituir efetivamente uma violação de regras legais (Xu \& Shenkar, 2002). Portanto, as EMNs podem necessitar do apoio de parceiros locais para aprender e incorporar essas regras invisíveis nas suas ações. Por exemplo, um relatório da consultora Ernst \& Young notou que, apesar do crescimento do investimento estrangeiro direto na África, ainda corresponde a somente $5,5 \%$ dos investimentos estrangeiros mundiais. Também o Brasil tem investimentos tímidos na África. Uma das justificativas é a desconfiança face à instabilidade política, à corrupção e às dificuldades em fazer negócios nos países africanos, onde, além das dificuldades regulatórias - que promovem a propensão à corrupção e ao suborno como formas de ultrapassar as ineficácias formais, junta-se um conjunto de aspectos cognitivos e normativos que criam barreiras e custos adicionais.

A diferenciação que se estabeleceu acima contrasta as dimensões cognitiva e normativa de um lado e a regulatória de outro. Enquanto as primeiras são implícitas, tácitas e difíceis de codificar e aprender, a dimensão regulatória envolve normas e regulamentações explícitas e facilmente identificáveis pelas EMNs. Assim, é razoável propor que as parcerias com empresas locais são mais importantes para compreender as dimensões normativa e cognitiva do que para entender as ações e implicações das instituições regulatórias. Na forma de proposição: 
Proposição 2. EMNs entrando em países com ambientes institucionais normativo e cognitivo diferentes mais provavelmente selecionarão estratégias de entrada de parcerias (como joint ventures, alianças estratégicas e aquisições parciais) do que quando entram em ambientes regulatórios diferentes.

Um exemplo ilustrativo é o da entrada da O Boticário em Portugal. A O Boticário iniciou a internacionalização há mais de 25 anos com um investimento greenfield em Lisboa, Portugal, em 1986. Para consolidar o negócio em Portugal a empresa levou quase duas décadas. Os erros apontados incluem a não adaptação de catálogos (Português brasileiro versus Português de Portugal), a não adaptação dos produtos aos mercados (fragrâncias dos perfumes, cores das maquiagens, etc.), a falta de assistência adequada aos franqueados que se queixavam de incompreensão do mercado local (Hilal \& Hemais, 2003; Naiditch, 2007), entre outros. Nesse caso, teria sido mais adequado entrar em Portugal com uma estratégia de parceria em vez de realizarem logo uma operação de investimento direto. $\mathrm{O}$ fato é que a $\mathrm{O}$ Boticário não conhecia nem a cultura nem todo o sistema institucional português.

\section{Distância institucional entre o país receptor e o país de origem}

A distância institucional dificulta o fluxo de informação entre a EMN e o mercado (Eden \& Miller, 2004; Kostova, 1999; Kostova et al., 2008; Phillips, Tracey, \& Karra, 2009; Xu \& Shenkar, 2002) e pode promover a adoção de estratégias que não são as mais eficientes, mas apenas as mais legítimas. Por exemplo, ao entrar em ambientes institucionais mais distintos do seu país de origem, a EMN pode optar por comprometer menos recursos às operações nesse país, como resposta racional para reduzir o risco. Portanto, na entrada em países com elevada distância institucional, a melhor estratégia para a EMN pode estar em estratégias de entrada que envolvam pouco ou nenhum investimento de capital.

Quanto maior a distância institucional ao país receptor, maior será, estereotipicamente, o grau de adaptação necessário dos produtos e serviços, em primeira instância, mas possivelmente também dos modelos de organização e gestão. Em essência, maior distância institucional entre a origem e o receptor requer a necessidade de avaliar, aprender e adaptar mais extensivamente a normas, regras, formas de organização e procedimentos locais (Kostova \& Roth, 2002). O modelo de internacionalização gradual da escola de Upsalla recomendaria que a estratégia de entrada mais racional seja a exportação, porque a empresa incorre em menor risco e necessita menor compromisso de recursos (Johanson \& Mattsson, 1988) enquanto aprende sobre o ambiente institucional local. J.-T. Li e Guisinger (1991), por exemplo, notaram que a taxa de insucesso na internacionalização das empresas norte-americanas aumentava quando as empresas se expandiam para países muito diferentes, com ambientes institucionais mais distintos. Assim, propõe-se:

Proposição 3. EMNs a entrar em mercados institucionalmente mais distantes mais provavelmente escolherão estratégia de entrada através de exportação que qualquer outra estratégia de entrada.

O exemplo da brasileira Petrobras ajuda a ilustrar. Ela cresceu para a Bolívia através de uma operação greenfield para a produção e comercialização de gás natural. A Bolívia é um país com sistema institucional menos estabelecido, instável e substancialmente diferente do brasileiro (Cuervo-Cazurra, 2008). O fato é que, em 2006, o governo boliviano criou a empresa estatal Yacimientos Petrolíferos Fiscales Bolivianos (YPFB), para assumir as operações de comercialização da produção, passando a ser responsável pelas condições, volumes e preços, quer para o mercado interno, quer para a exportação. Assim, a Petrobras viu as suas operações na Bolívia nacionalizadas (Ribeiro \& Borini, 2010). A empresa fez investimento direto num país onde a segurança institucional era baixa, mas onde o objetivo estratégico era garantir gás para o Brasil. Outras alternativas poderiam ter sido avaliadas - como a possibilidade de importação do gás, eventualmente, assegurando assistência técnica e formação de mão de obra na Bolívia - no lugar de criar uma operação própria. Em contraponto, na indústria brasileira de serviços, é evidente, segundo Macadar (2009), a preferência por exportação para mercados psiquicamente mais distantes.

É possível que, em alguns casos, a EMN necessite ter um parceiro local para poder operar. Por exemplo, em países onde existem restrições à posse por capital estrangeiro de empresas locais, como 
vigorou durante muitos anos na China. Para obviar aos impedimentos legais regulatórios, a escolha de mecanismos cooperativos, como joint ventures, alianças estratégicas e as aquisições parciais, pode ser a forma de entrada viável nesses mercados. É de salientar que, tipicamente, esse tipo de requisitos é mais frequente em países menos desenvolvidos ou de desenvolvimento intermédio, onde também o ambiente institucional é menos desenvolvido (Peng et al., 2008). Assim, a escolha estratégica visa ultrapassar os impedimentos, mas, simultaneamente, reduzir os custos de transação que tendem a acompanhar essas restrições.

O exemplo da Marcopolo que, em 2006, realizou uma joint venture com a indiana Tata Motors ilustra essa proposição. Nessa operação, a Marcopolo detém $49 \%$ e a Tata, $51 \%$. A produção da joint venture é orientada para o mercado indiano e para exportação, com uma linha de produtos diversificada. A Marcopolo focaliza na sua competência de produção de carrocerias, e a Tata Motors fornece os chassis e os canais de comercialização. Assim, a Marcopolo reduz a exposição e risco ao mercado e consegue entrar num país que protege as encarroçadoras locais com elevados impostos de importação (Macadar, 2009). Também na Rússia entrou com uma joint venture, em 2007, tal como na China em 2001 (Rosa \& Rhoden, 2007). As barreiras legais, restrições à posse por empresas estrangeiras e barreiras não tarifárias como o favorecimento de empresas locais são restrições a observar. Na internacionalização da Banca, Nunes et al. (2011) revelaram que, sendo uma atividade fortemente regulada e com quesitos específicos, o Itaú cresceu abrindo escritórios e por meio de parcerias. Ou o caso da elétrica portuguesa EDP, que teve de estabelecer parceria com a estatal Eletrobrás para o desenvolvimento de centrais hidroelétricas no Brasil devido aos requisitos legais (Fernandes, Bandeira-de-Mello, \& Zanni, 2012). As restrições legais e à posse por capital estrangeiro estarão na base da joint venture da Embraer com um parceiro local para entrar na China (Fleury \& Fleury, 2011). Então, uma proposição complementar é:

Proposição 3a. Se em mercados institucionalmente mais distantes existirem, ainda, requisitos legais específicos, as EMNs mais provavelmente escolherão estratégias de parcerias (joint ventures, alianças estratégicas e aquisições parciais) que qualquer outra estratégia de entrada.

\section{Estrutura da distância institucional}

Além da distância institucional entre o país de origem e de destino, é importante considerar como a diferença é estruturada (Shenkar, 2001; Xu \& Shenkar, 2002). O país receptor e o de origem podem estar em diferentes estágios de desenvolvimento institucional. Para efeitos de exposição, delineam-se apenas dois cenários, com efeitos assimétricos, para a distância institucional entre dois países: (a) o país de origem tem um sistema institucional mais imaturo que o país de receptor (é o caso de uma EMN emergente a entrar na Europa ou nos EUA); e (b) o país de origem tem um sistema institucional mais desenvolvido que o país receptor (é o caso de uma EMN europeia entrar numa economia emergente). É provável que a estratégia de internacionalização das EMNs difira entre os dois cenários (Xu \& Shenkar, 2002).

Para entrar em países institucionalmente mais desenvolvidos (cenário 1), as estratégias de parceria parecem menos importantes, porque esses países têm instituições bem-estruturadas e eficazes que facilitam a internacionalização (Henisz, 2000; K. Meyer \& Peng, 2005). Os custos de transação envolvidos serão menores. Como esses países têm mercados e empresas mais sofisticados, é possível que as EMNs que pretendam entrar neles necessitem deter uma vantagem de capacidades ou recursos intangíveis (por exemplo, conhecimento) (Dunning, 1988, 1998; Kogut \& Zander, 1993). O caso da Marcopolo, sustentada em competências nas carrocerias, exposto anteriormente, enquadra-se nesse cenário. Para guardar e proteger internamente as suas vantagens específicas, a estratégia de mitigação dos riscos possivelmente assentará na escolha de estratégias de entrada que se materializam na posse (e controle) integral das suas subsidiárias no estrangeiro (Buckley \& Casson, 1976; Dunning, 1998). Na realidade, não há evidência explícita de que as EMNs emergentes tenham uma vantagem para, por exemplo, formar uma parceria com uma empresa europeia e as motivações prendem-se com a aprendizagem tecnológica e aceder aos mercados (Cuervo-Cazurra, 2008); uma racionalidade que se afasta dos argumentos institucionais. 
Em contraste, quando as EMNs entram em países institucionalmente primitivos, oriundas de países mais desenvolvidos (cenário 2), podem preferir estratégias de parceria como forma de prevenir possíveis custos e riscos de normas e regras locais (Chen \& Chen, 1998; Johanson \& Mattsson, 1988), ineficiências e todo um leque de práticas informais. Em alguns países, embora mais primitivos, não existe um mercado de fatores que permita as parcerias ou as aquisições, como parece evidenciado na internacionalização da Odebrecht para Angola em meados dos anos 1980 (Zebinden, Oliva, \& Gaspar, 2007). Diferente é o acordo que a inglesa Jaguar Land Rover (detida pela indiana Tata Motors) fechou para uma joint venture com a chinesa Chery Automobile para fabricação e comercialização de seus automóveis na China (Wachman, 2012). Essa opção por uma estratégia colaborativa, considerando que a Inglaterra é um país com um sistema institucional bem desenvolvido e a China ainda está em uma fase mais incipiente, parece ter sido adequada para a entrada no mercado chinês. Assim, propõe-se que:

Proposição 4. EMNs de países com um sistema institucional mais desenvolvido a entrar em países institucionalmente menos desenvolvidos mais provavelmente selecionarão estratégias de entrada através de parcerias (joint ventures, alianças estratégicas e aquisições parciais) ou aquisições totais de empresas locais que outros modos de entrada.

Proposição 4a. EMNs de países com sistemas institucionais mais primitivos a entrar países institucionalmente mais desenvolvidos mais provavelmente escolherão estratégias de investimentos de raiz.

O exemplo da brasileira Marcopolo ilustra as proposições. A empresa é uma das mais internacionalizadas do Brasil (Cuervo-Cazurra, 2008), com operações em diversos países pelo mundo. Em geral, a estratégia das empresas de ônibus é atender à demanda local, o que faz da Marcopolo uma exceção. Ela ou vende suas carrocerias de ônibus desmontados ou possui fábricas nos mercados mais importantes (Macadar, 2009), nesse caso investindo em fábricas de montagem (Rosa \& Rhoden, 2007; Serra \& Ferreira, 2013; Stal, 2010). Na internacionalização para Portugal, onde os sistemas institucionais são desenvolvidos, a Marcopolo possui um investimento de raiz, como sugerido na proposição 4a. Já na Índia, a empresa tem uma operação conjunta com a Tata Motors, com duas fábricas em operação, exemplificando uma escolha de uma estratégia de parceira ao entrar em países menos desenvolvidos, como sugerido na proposição 4.

\section{O ambiente institucional interno das EMNs}

As estratégias de entrada nos mercados externos também são determinadas por pressões internas à própria EMN, que se revelam nas pressões para a conformidade entre as subsidiárias no estrangeiro (DiMaggio \& Powell, 1983; J. Meyer \& Rowan, 1977; Kostova, 1999; Oliver, 1997; Xu \& Shenkar, 2002). As pressões internas incluem as estruturas organizacionais, missão e visão corporativa, objetivos da EMN, normas, valores e tradições, relações de poder, coalizações dominantes e cultura organizacional (ver Figura 1). Por exemplo, as EMNs podem favorecer um elevado grau de controle e coordenação das subsidiárias, o que conduz a elevado grau de isomorfismo entre as subsidiárias e com a sede corporativa (Davis et al., 2000; Scherer et al., 2009).

As pressões das instituições internas conduzem a EMN a escolher estratégias que minimizem o impacto na empresa. Os investimentos diretos de raiz permitem continuar a replicar as estruturas internas e os valores normativos, com menores disrupções internas. Realizando investimentos de raiz, a EMN mantém o controle total sobre as suas operações no estrangeiro, mas padece de ter menor adaptação às pressões institucionais dos mercados receptores. Como Davis, Desai e Francis (2000, p. 243) afirmam, "quando as empresas mãe exercem maior controle, as pressões para manter o isomorfismo interno podem ser superiores às pressões para o isomorfismo com o ambiente externo".

Outras formas de investimento podem não ser adequadas. Especificamente, pode-se esperar que a aquisição de uma empresa existente cause maior perturbação na estabilidade e cultura dominante da EMN. Esse parece ter sido o caso com a aquisição da Inco pela CVRD, discutida acima, que revelou problemas internos. A Inco vivia sobre forte nível de sindicalismo e organização dos trabalhadores. A CRVD, ao tentar impor os seus padrões e procedimentos sobre a adquirida Inco, gerou forte disputa com 
os trabalhadores, que culminaram em greves e processos junto à justiça do trabalho no Canadá, e a condenação por práticas injustas de trabalho (F. Ferreira \& Carneiro, 2009). O histórico de internacionalização da Natura revela essas dificuldades, com a empresa a adotar estruturas distintas para a sua internacionalização para a América Latina e para a Europa e EUA (Alem \& Cavalcanti, 2005). As pressões institucionais internas influenciam a escolha de estratégias colaborativas. As parcerias possivelmente conduzem a maiores disrupções internas porque a participação em alianças ou joint ventures impõe maior coordenação e controlo entre empresas.

Proposição 5. As EMNs tenderão a selecionar estratégias de entrada através de estratégias de parcerias (joint ventures, alianças estratégicas) ou aquisições quando as pressões institucionais internas são menores e a selecionar estratégias de exportação e de investimento de raiz quando as pressões internas são maiores.

\section{Discussão e Notas Finais}

As empresas crescem internacionalmente para melhorar o seu desempenho e aumentar vendas, cota de mercado, lucros e poder. A perspectiva tradicional em negócios internacionais assentava-se na ideia de que as empresas realizariam investimento direto no estrangeiro, para aumentar o seu desempenho alavancando as suas vantagens específicas em outros mercados (Buckley \& Casson, 1976; Hennart, 1982). Essas vantagens, que seriam transferidas para as subsidiárias no estrangeiro, deveriam ser suficientes para ultrapassar as desvantagens de ser estrangeiro (Hymer, 1976). A existência dessas vantagens era uma condição sine qua non para a própria existência da multinacional (Buckley \& Casson, 1976). Os benefícios da presença internacional poderiam advir de novas aprendizagens, que seriam transferidas internamente entre a rede de subsidiárias (Bartlett \& Ghoshal, 1989), mas também da possibilidade de arbitragem, dos preços de transferência internos face a níveis diferentes de fiscalidade e do acesso a fatores produtivos mais baratos, mais produtivos ou mais sofisticados. No entanto, para explorar e alavancar competências, tal como para aprender e aumentá-las, a EMN precisa deter operações locais ajustadas ao ambiente institucional externo e interno. É, assim, premente incluir no debate uma maior consideração dos fatores sociais.

Este artigo contribui para a pesquisa sobre o impacto das pressões sociais - especificamente do ambiente institucional - nas estratégias de entrada das EMNs no estrangeiro. Para aumentar a probabilidade de sucesso, as EMNs precisam selecionar a melhor estratégia face às várias facetas e condicionantes institucionais (D. Li et al., 2012; D. Li \& Ferreira, 2011; Oliver, 1997). Seguindo a literatura existente, discutiu-se conceitualmente a existência de pressões duais - as do ambiente externo e as internas à própria EMN - para aprofundar sobre a racionalidade estratégica na seleção da estratégia de entrada, em condições de racionalidade limitada dos agentes (Simon, 1991; Williamson, 1985). No fundo, esse é o reconhecimento que muitas escolhas estratégicas - incluindo a estratégia de entrada no estrangeiro - podem não ser orientadas exclusivamente por objetivos de racionalidade econômica de maximização dos lucros (DiMaggio \& Powell, 1983) e, ao contrário, as dinâmicas sociais podem prevalecer. Talvez uma conclusão seja que as EMNs estão condicionadas a escolher entre um leque de alternativas mais restrito do que é geralmente assumido, pelo que pesquisa futura nessa sequência seria recomendável. Finalmente, acrescenta-se, em linha com pesquisa recente (Xu \& Shenkar, 2002), como a distância institucional (Kostova, 1999; Kostova et al., 2008; Kostova \& Zaheer, 1999) entre o país de origem e receptor tem a capacidade de influenciar a estratégia de internacionalização.

As pressões institucionais duais precisam ser refletidas nas escolhas estratégicas das empresas. Enquanto a teoria institucional assenta-se no pressuposto de que as EMNs precisam ganhar legitimidade nos mercados locais, adaptando-se aos valores, às normas, ações, estruturas e formas localmente prevalecentes de como fazer as coisas - ou seja, às expectativas e influências sociais, também precisam atender à forma como as subsidiárias nesses mercados se integram no todo que é a EMN em rede (Bartlett \& Ghoshal, 1989). O contraste é evidente com as teorias da estratégia, assentes nas escolhas que permitem maior desempenho, maior eficiência e eficácia, dados os condicionalismos internos e 
externos e os objetivos para o futuro. Assim, a utilização de uma perspectiva institucional na estratégia revela que a conformidade às pressões sociais duais, externas e internas, entra em contraponto com as escolhas estratégicas ótimas das EMNs. A evidência, mesmo casuística, parece revelar que as EMNs frequentemente subestimam os aspectos institucionais na sua atuação no estrangeiro.

Neste artigo, formulou-se um conjunto de proposições conceituais úteis para os gestores considerarem na expansão internacional - exigindo que reflitam não somente com base na sua estratégia ou otimização de eficiência. Os sistemas institucionais, sejam do país receptor, do país de origem ou os da própria empresa sobre a subsidiária no estrangeiro, vão influenciar ações e resultados. A Tabela 1 apresenta de forma organizada as proposições deste trabalho. Além do texto das proposições e de assinalar se a proposição é alternativa ou complementar, apresenta-se de forma esquemática e elucidativa como um gestor poderia refletir sobre a influência institucional na decisão do modo de entrada, de forma a auxiliá-lo no dimensionamento dos riscos. Considera-se, assim, que, apesar de ainda merecerem testes empíricos, as proposições possibilitam desde já alguma aplicação prática.

Tabela 1

Avaliar as Estratégias de Entrada nos Mercados Externos

\begin{tabular}{|c|c|c|c|}
\hline Proposição & Proposta & Sistema do país receptor & Modo de entrada \\
\hline 1 & $\begin{array}{l}\text { EMNs entrando em países com um sistema } \\
\text { institucional bem-estabelecido mais } \\
\text { provavelmente usarão estratégias de entrada } \\
\text { baseadas em parcerias, em oposição a } \\
\text { estratégias de entrada por exportação ou } \\
\text { investimentos de raiz. }\end{array}$ & $\begin{array}{l}\text { Sistema institucional bem- } \\
\text { estabelecido }\end{array}$ & Parcerias \\
\hline $\begin{array}{l}\text { la } \\
\text { (alternativa à } \\
\text { P1) }\end{array}$ & $\begin{array}{l}\text { EMNs entrando em países com um sistema } \\
\text { institucional bem-estabelecido mais } \\
\text { provavelmente usarão estratégias de } \\
\text { investimento de raiz ou aquisições totais. }\end{array}$ & $\begin{array}{l}\text { Sistema institucional bem- } \\
\text { estabelecido }\end{array}$ & $\begin{array}{l}\text { Investimentos de } \\
\text { raiz ou aquisições } \\
\text { totais }\end{array}$ \\
\hline 2 & $\begin{array}{l}\text { EMNs entrando países com ambientes } \\
\text { institucionais normativo e cognitivo } \\
\text { diferentes mais provavelmente selecionarão } \\
\text { estratégias de entrada de parcerias (como } \\
\text { joint ventures, alianças estratégicas e } \\
\text { aquisições parciais) do que quando entram } \\
\text { em ambientes regulatórios diferentes. }\end{array}$ & Normativo e cognitivo $\neq$ & Parcerias \\
\hline 3 & $\begin{array}{l}\text { EMNs entrando em mercados } \\
\text { institucionalmente mais distantes mais } \\
\text { provavelmente escolherão estratégia de } \\
\text { entrada através de exportação que qualquer } \\
\text { outra. }\end{array}$ & Institucional $\neq$ & Exportação \\
\hline $\begin{array}{l}3 \mathrm{a} \\
\text { (comlementar } \\
\text { à P3) }\end{array}$ & $\begin{array}{l}\text { Se em mercados institucionalmente mais } \\
\text { distantes existirem, ainda, requisitos legais } \\
\text { específicos, as EMNs mais provavelmente } \\
\text { escolherão estratégias de parcerias ou } \\
\text { colaborativas (joint ventures, alianças } \\
\text { estratégicas e aquisições parciais) que } \\
\text { qualquer outra estratégia de entrada. }\end{array}$ & $\begin{array}{l}\text { Institucional } \neq \text { legal } \\
\text { específico }\end{array}$ & $\begin{array}{l}\text { Parcerias ou } \\
\text { colaboração }\end{array}$ \\
\hline
\end{tabular}

Continua 


\section{Tabela 1 (continuação)}

\begin{tabular}{|c|c|c|c|}
\hline Proposição & Proposta & Sistema do país receptor & Modo de entrada \\
\hline 4 & $\begin{array}{l}\text { EMNs de países com um sistema } \\
\text { institucional mais desenvolvido a entrar em } \\
\text { países institucionalmente menos } \\
\text { desenvolvidos mais provavelmente } \\
\text { selecionarão estratégias de entrada através } \\
\text { de parcerias (joint ventures, alianças } \\
\text { estratégicas e aquisições parciais) ou } \\
\text { aquisições totais de empresas locais, que } \\
\text { outros modos de entrada. }\end{array}$ & $\begin{array}{l}\text { Sistema institucional } \\
\text { menos desenvolvido }\end{array}$ & $\begin{array}{l}\text { Parcerias, ou } \\
\text { aquisições totais de } \\
\text { empresas locais }\end{array}$ \\
\hline $\begin{array}{l}4 \mathrm{a} \\
\text { (complementar } \\
\text { à P4) }\end{array}$ & $\begin{array}{l}\text { EMNs de países com sistemas institucionais } \\
\text { mais primitivos a entrar países } \\
\text { institucionalmente mais desenvolvidos mais } \\
\text { provavelmente escolherão estratégias de } \\
\text { investimentos de raiz. }\end{array}$ & $\begin{array}{l}\text { Sistema institucional mais } \\
\text { desenvolvido de origem } \\
\text { com sistema mais } \\
\text { primitivo) }\end{array}$ & $\begin{array}{l}\text { Investimentos de } \\
\text { raiz }\end{array}$ \\
\hline 5 & $\begin{array}{l}\text { As EMNs tenderão a selecionar estratégias } \\
\text { de entrada através de estratégias de } \\
\text { parcerias (joint ventures, alianças } \\
\text { estratégicas) ou aquisições quando as } \\
\text { pressões institucionais internas são menores } \\
\text { e a selecionar estratégias exportação e de } \\
\text { investimento de raiz quando as pressões } \\
\text { internas são maiores. }\end{array}$ & $\begin{array}{l}\text { Pressões institucionais } \\
\text { internas baixas na EMN } \\
\text { Pressões institucionais } \\
\text { internas altas na EMN }\end{array}$ & $\begin{array}{l}\text { Parcerias ou } \\
\text { aquisições } \\
\text { Exportação e } \\
\text { investimento de } \\
\text { raiz }\end{array}$ \\
\hline
\end{tabular}

Nota. Fonte: Elaborado pelos autores.

\section{Investigação futura}

Embora neste artigo se integrem diversos componentes do ambiente institucional externo e interno, não se pretende elaborar um modelo exaustivo dada a complexidade dos efeitos. As proposições conceituais visam ser apenas ilustrativas e merecem investigação futura. Por exemplo, é possível que as pressões institucionais variem com a indústria (Henisz, 2000), como ocorrerá nas indústrias militar, de transportes, telecomunicações, energia, educação, saúde e em outras nas quais o governo impõe restrições diversas, nomeadamente à participação de capital estrangeiro. Nessas indústrias, a necessidade de adaptação aos requisitos locais é mandatória, pelo que a estratégia de entrada adotada possivelmente resultará mais de imposição que de escolha estratégica. Nesses casos, as estratégias de entrada podem requerer o investimento direto em subsidiárias fabris no país receptor ou o estabelecimento de parcerias com empresas locais, não permitindo o serviço do mercado através de exportação.

É possível estabelecer formas de testar empiricamente as proposições avançadas neste trabalho. Os modos de entrada que as empresas escolhem para cada país podem ser obtidos de fontes secundárias (como relatórios internos ou notícias nos midia) ou por questionário dedicado. Também a caracterização dos ambientes institucionais do país de origem e receptor é possível de se obter por meio de questionário ou utilizando métricas que se vão tornando mais comuns para as várias dimensões do ambiente institucional. A esse respeito importa salientar a taxonomia de distância CAGE - cultural, administrativa, geográfica e econômica - proposta por Ghemawat (2001) ou a mais recente taxonomia de Berry, Guillén e Zhou (2010), que distingue nove dimensões do ambiente institucional - econômica, financeira, política, administrativa, cultural, demográfica, de conhecimento, conexões globais e geográfica - e disponibiliza métricas para avaliar as distâncias institucionais entre os países. A desagregação que essas taxonomias permitem tem a vantagem adicional de proporcionar o entendimento dos impactos específicos de dimensões institucionais sobre as relações em causa: a escolha do modo de entrada no estrangeiro, em vez de apenas tratar uma dimensão de distância, ou diferença institucional. Outras 
métricas podem mais simplesmente usar os dados disponibilizados publicamente por organizações transnacionais como o Banco Mundial.

Pesquisa futura pode seguir outras linhas ainda pouco compreendidas. Por exemplo, como as estratégias de entrada são influenciadas por fatores específicos à empresa, como sejam o tipo de tecnologia e conhecimento incorporados nos produtos e processos, o nível de experiência internacional que já detêm, as parcerias com outras empresas que protegem de ameaças externas, etc. Esses fatores possivelmente influenciarão a forma como a empresa reage às pressões institucionais externas. Mas também podem impor um conjunto de pressões internas para a conformidade com as experiências prévias.

Pesquisa futura pode, ainda, buscar compreender, no quadro da teoria institucional, como as ações dos competidores e as estratégias que utilizam são imitadas, na procura da legitimidade (ver D. Li et al., 2012; Martin et al., 1998). Essa linha de pesquisa envolve os conceitos de mimetismo e isomorfismo, sugerindo que as empresas tendem a imitar outras que parecem estar bem-sucedidas (Haunschild \& Miner, 1997; Henisz \& Delios, 2001), num leque diverso de ações estratégicas, incluindo, previsivelmente, os modos de entrada. A esse respeito, M. P. Ferreira et al. (2008) sugeriram que as EMNs tenderão, provavelmente, a imitar outras quando entram em mercados que ainda não conhecem, mas não especificaram quais as empresas que imitam e quais os critérios usados para a escolha das empresas a imitar. D. Li, Miller e Eden (2012) focaram o isomorfismo, mas apenas usando três modos de entrada nos EUA. Baseando-se na teoria institucional, pode-se propor que, ao entrar em países institucionalmente mais desenvolvidos - onde os riscos serão estereotipicamente menores, talvez a tendência de imitação seja menor. Possivelmente, é na entrada em países institucionalmente mais imaturos que a tendência de imitação será maior. No entanto essas propostas conceituais merecem estudos futuros.

Pesquisa futura também pode envolver entender como a experiência internacional prévia das EMNs influencia as estratégias de entrada. De fato, é provável que as EMNs usem da sua experiência anterior, inclusive em outros mercados estrangeiros, e da sua capacidade de alavancar ativos geograficamente dispersos, para ultrapassar algumas das desvantagens de ser estrangeiro (Hymer, 1976; Kogut \& Zander, 1993). A experiência internacional genérica tem o potencial de auxiliar a entender as idiossincrasias das instituições locais e facilitar o entendimento das ações necessárias para ganhar legitimidade (M. P. Ferreira, 2008). Para inquirir nesse sentido, seria relevante examinar se, e como, os recursos e competências internos da EMN conduzem à adoção de uma só estratégia (a uniform script) para todas as entradas em países estrangeiros ou, pelo contrário, se a EMN escolherá um modo absolutamente adaptado para cada um dos países. Essas propostas de pesquisa futura envolvem não apenas o teste empírico às proposições formuladas neste artigo, mas também a inclusão de efeitos moderadores sobre as relações propostas.

Uma via potencialmente relevante é observar as EMNs como redes de subsidiárias (Bartlett \& Ghoshal, 1989) em diferentes ambientes institucionais, dos quais sofrem pressões para a legitimidade (Rosenzweig \& Singh, 1991; Xu \& Shenkar, 2002). Esse contexto permite testar como as EMNs reagem às pressões para a integração global e para a adaptação local e como o modo de entrada escolhido reflete essa tensão dual. Esse é, também, o contexto em que se pode observar a influência relativa do ambiente institucional do país de origem e do país receptor, que Rosenzweig e Singh (1991) postularam ser dependente de outros fatores estratégicos e estruturais. Especificamente, é relevante entender, na sequência de Kostova e Zaheer (1999), como as maiores distâncias institucionais tornam mais difícil às EMNs transferir para as suas subsidiárias as vantagens competitivas. Ou seja, as diferenças institucionais dificultam o equilíbrio entre a legitimidade externa (ou a adaptação ao mercado receptor) e a conformidade interna à EMN (ou a integração global das subsidiárias na rede).

As extensões na pesquisa podem incluir, ainda, o trazer outras teorias para o debate. Como Kogut e Singh (1988) notaram, pode-se usar as contribuições da teoria dos custos de transação conjugada com fatores culturais e institucionais. A Visão Baseada em Recursos (VBR) permitirá compreender a alavancagem internacional dos recursos e como as competências das EMNs podem gerar resistência a 
ações que visem à legitimidade local. Por exemplo, uma questão imediata que surge é se as competências específicas às EMNs são uma barreira a conseguir legitimidade local.

Tendo focado nas pressões externas, não foi propósito deste artigo distinguir como diferentes dimensões do ambiente institucional externo podem levar a diferentes modos de entrada. Por exemplo, Oliver (1991) argumentou que as pressões institucionais legais são quase absolutamente determinantes das estratégias das empresas. Isso é evidente quando, por exemplo, um governo limita a posse de capital por empresas estrangeiras. Efeitos diferentes podem resultar das pressões cognitivas e regulatórias. Ou seja, é razoável sugerir, como M. P. Ferreira et al. (2008), que diferentes facetas do ambiente institucional tenham influências também diferentes sobre as estratégias.

Para concluir, os ambientes institucionais - externo e interno - têm um impacto significativo nas estratégias de internacionalização das multinacionais. A teoria institucional permite uma abordagem à forma como as pressões institucionais duais precisam ser incorporadas na estratégia e mostra que as de internacionalização podem não ser o resultado único de ações da mais pura racionalidade econômica no sentido da maximização de lucros e da eficiência. Por exemplo, enquanto os modos de entrada através de investimentos de raiz (investimentos greenfield) podem ser favorecidos quando as pressões institucionais do país receptor são baixas, os modos de entrada de maior compromisso de recursos também permitem absorver a incerteza local e aumentar a legitimidade da subsidiária no país receptor. A adoção de estratégias intermédias, ou híbridas, tais como as joint ventures e as alianças estratégicas, podem ser mais dependentes do nível de desenvolvimento institucional do país receptor. Assim, as estratégias das EMNs são influenciadas, mas não absolutamente prescritas (Oliver, 1997), pelos ambientes instituicionais em que as subsidiárias operam, e as pressões institucionais também não se sobreporão sempre a uma escolha entre estratégias alternativas.

\section{Referências}

Alem, A., \& Cavalcanti, C. (2005). O BNDES e o apoio à internacionalização das empresas brasileiras: algumas reflexões. Revista do BNDES, 12(24), 43-76.

Anand, J., \& Delios, A. (2002). Absolute and relative resources as determinants of internal acquisitions. Strategic Management Journal, 23(2), 119-134. doi: 10.1002/smj.215

Andrade, A. M. F. de, \& Galina, S. V. R. (2013). Efeitos da internacionalização sobre o desempenho de multinacionais de economias em desenvolvimento. Revista de Administração Contemporânea, 17(2), 239-262. Recuperado de http://www.scielo.br/pdf/rac/v17n2/07.pdf. doi: 10.1590/S141565552013000200007

Barney, J. (1991). Firm resources and sustained competitive advantage. Journal of Management, 17(1), 99-120. doi: 10.1177/014920639101700108

Bartlett, C., \& Ghoshal, S. (1989). Managing across borders: the transnational solution. Boston, Mass: Harvard Business School Press.

Berry, H., Guillén, M. F., \& Zhou, N. (2010). An institutional approach to cross-national distance. Journal of International Business Studies, 41(9), 1460-1480. doi: 10.1057/jibs.2010.28

Bevan, A., Estrin, S., \& Meyer, K. (2004). Institution building and the integration of Eastern Europe in international production. International Business Review, 13(1), 43-64. doi: 10.1016/j.ibusrev.2003.05.005

Boehe, D., \& Zawislak, P. (2007). Influências ambientais e inovação de produtos: estudo de casos em subsidiárias de multinacionais no Brasil. Revista de Administração Contemporânea, 11(1), 97 117. doi: 10.1590/S1415-65552007000100006 
Buckley, P., \& Casson, M. (1976). The future of the multinational enterprise. London: Macmillan.

Chen, H., \& Chen, T.-Y. (1998). Network linkages and location choice in foreign direct investment. Journal of International Business Studies, 29(3), 445-467. doi: 10.1057/palgrave.jibs. 8490002

Cuervo-Cazurra, A. (2008). The multinationalization of developing country MNEs: the case of multilatinas. Journal of International Management, 14(2), 138-154. doi: 10.1016/j.intman.2007.09.001

Dacin, M. T. (1997). Isomorphism in context: the power and prescription of institutional norms. Academy of Management Journal, 40(1), 46-81. doi: 10.2307/257020

Davis, P. S., Desai, A. B., \& Francis, J. D. (2000). Mode of international entry: an isomorphism perspective. Journal of International Business Studies, 31(2), 239-258. doi: 10.1057/palgrave.jibs.8490904

Delios, A., \& Beamish, P. W. (1999). Ownership strategy of Japanese firms: transactional, institutional, and experience influences. Strategic Management Journal, 20(10), 915-933. doi: 10.1002/(SICI)1097-0266(199910)20:10<915::AID-SMJ51>3.0.CO;2-0

Dias, A., Rocha, A., \& Silva, J. (2014). Modos de entrada no investimento direto no exterior: um estudo da literatura empírica. Revista de Administração Contemporânea, 18(4), 416-445. Recuperado de http://www.scielo.br/pdf/rac/v18n4/1415-6555-rac-18-04-00416.pdf. doi: 10.1590/19827849rac20141110

Dikova, D., \& Witteloostuijn, A. van (2007). Foreign direct investment mode choice: entry and establishment modes in transition economies. Journal of International Business Studies, 38(6), 1013-1033. doi: 10.1057/palgrave.jibs.8400297

DiMaggio, P. J., \& Powell, W. W. (1983). The iron cage revisited: institutional isomorphism and collective rationality in organizational fields. American Sociological Review, 48(2), 147-160.

Dunning, J. H. (1988). The eclectic paradigm of international production: a restatement and some possible extensions. Journal of International Business Studies, 19(1), 1-31. doi: 10.1057/palgrave.jibs. 8490372

Dunning, J. H. (1995). Reappraising the eclectic paradigm in an age of alliance capitalism. Journal of International Business Studies, 26(3), 461-491. doi: 10.1057/palgrave.jibs.8490183

Dunning, J. H. (1998). Location and the multinational enterprise: a neglected factor? Journal of International Business Studies, 29(1), 45-66. doi: 10.1057/palgrave.jibs.8490024

Eden, L., \& Miller, S. R. (2004). Distance matters: liability of foreignness, institutional distance and ownership strategy. In M. Hitt \& J. Cheng (Eds.), Advances in international management (pp. 187-221). New York, NY: Elsevier.

Fernandes, C. M. A., Bandeira-de-Mello, R., \& Zanni, P. P. (2012). O papel dos fatores políticos na internacionalização de empresas: o caso da energias de Portugal (EDP) no Brasil. Cadernos EBAPE, 10(2), 435-455. doi: 10.1590/S1679-39512012000200011

Ferreira, F., \& Carneiro, J. (2009, novembro). A aquisição da Inco pela Vale: desafios e riscos em uma aquisição internacional. Anais do Encontro de Ensino e Pesquisa em Administração e Contabilidade, Curitiba, PR, Brasil, 2.

Ferreira, M. P. (2008). Building and leveraging knowledge capabilities through cross-border acquisitions. In S. Tallman (Ed.), New generations in international strategy (pp. 162-179). Northampton, MA: Edward Elgar Publishing, Ltd. 
Ferreira, M. P., Li, D., \& Jang, Y. (2009). Foreign entry strategies: strategic adaptation to the various facets of the institutional environments. Development and Society, 38(1), 27-55.

Ferreira, M. P., Li, D., Serra, F., \& Armagan, S. (2008). Composition of small and large firms' business networks in transition economies. Organizações \& Sociedade, 15(46), 195-213. doi: 10.1590/S1984-92302008000300010

Fleury, A., \& Fleury, M. (2011). Brazilian multinationals: competences for internationalization. Camdridge, UK: Cambridge University Presss.

Ghemawat, P. (2001). Distance still matters: the hard reality of global expansion. Harvard Business Review, 79(8), 137-147.

Gomes, R. C., \& Gomes, L. O. M. (2007). Proposing a theoretical framework to investigate the relationships between an organization and its environment. Revista de Administração Contemporânea, 11(1), 97-117. doi: 10.1590/S1415-65552007000100005

Granovetter, M. (1985). Economic action and social structure: the problem of embeddedness. American Journal of Sociology, 91(3), 481-510.

Guisinger, S. (2001). From OLI to OLMA: incorporating higher levels of environmental and structural complexity into the eclectic paradigm. International Journal of the Economics of Business, 8(2), 257-272. doi: 10.1080/13571510110051487

Haunschild, P., \& Miner, A. (1997). Modes of interorganizational imitation: the effects of outcome salience and uncertainty. Administrative Science Quarterly, 42(3), 472-500. doi: $10.2307 / 2393735$

Haveman, H. (1993). Follow the leader: mimetic isomorphism and entry into new markets. Administrative Science Quarterly, 38(4), 593-627. doi: 10.2307/2393338

Henisz, W. J. (2000). The institutional environment for multinational investment. Journal of Law Economics \& Organization, 16(2), 334-364. doi: 10.1093/jleo/16.2.334

Henisz, W. J., \& Delios, A. (2001). Uncertainty, imitation, and plant location: Japanese multinational corporations, 1990-1996. Administrative Science Quarterly, 46(3), 443-475. doi: $10.2307 / 3094871$

Hennart, J.-F. (1982). A theory of the multinational enterprise. Ann Arbor, MI: University of Michigan Press.

Hilal, A., \& Hemais, C. A. (2003). O processo de internacionalização na ótica da escola nórdica: evidências empíricas em empresas brasileiras. Revista de Administração Contemporânea, 7(1), 109-124. doi: 10.1590/S1415-65552003000100006

Hymer, S. (1976). The international operations of national firms: a study of direct foreign investment. Cambridge, MA: MIT Press.

Johanson, J., \& Mattsson, L.-G. (1988). Internationalization in industrial systems: a network approach. In N. Hood \& J.-E. Vahlne (Eds), Strategies in global competition (pp. 303-321), London, UK: Beckham.

Kogut, B., \& Singh, H. (1988). The effect of national culture on the choice of entry mode. Journal of International Business Studies, 19(3), 411-432. doi: 10.1057/palgrave.jibs.8490394

Kogut, B., \& Zander, U. (1993). Knowledge of the firm and evolutionary theory of the multinational corporation. Journal of International Business Studies, 24(4), 625-645. doi: 10.1057/palgrave.jibs. 8490248 
Kostova, T. (1999). Transnational transfer of strategic organizational practices: a contextual perspective. Academy of Management Review, 24(2), 308-324. doi: 10.5465/AMR.1999.1893938

Kostova, T., \& Roth, K. (2002). Adoption of an organizational practice by subsidiaries of multinational corporations: institutional and relational effects. Academy of Management Journal, 45(1), 215233. doi: $10.2307 / 3069293$

Kostova, T., Roth, K., \& Dacin, M. T. (2008). Institutional theory in the study of multinational corporations: a critique and new directions. Academy of Management Review, 33(4), 994-1006. doi: 10.5465/AMR.2008.34422026

Kostova, T., \& Zaheer, S. (1999). Organizational legitimacy under conditions of complexity: the case of the multinational enterprise. Academy of Management Review, 24(1), 64-81. doi: 10.5465/AMR.1999.1580441

Li, D., \& Ferreria, M. P. (2011). Institutional environment and firms' sources of financial capital in Central and Eastern Europe. Journal of Business Research, 64(4), 371-376. doi: 10.1016/j.jbusres.2010.08.013

Li, D., Miller, S., \& Eden, L. (2012). Entry mode decisions by emerging-market firms investing in developed markets. In L. Tihanyi, T. Devinney, \& T. Pedersen (Eds.), Institutional theory in international business and management (Vol. 25, pp. 207-231). Bingley, UK: Emerald Group Publishing Limited.

Li, J.-T., \& Guisinger, S. (1991). Comparative business failures of foreign-controlled firms in the United States. Journal of International Business Studies, 22(2), 209-224. doi: 10.1057/palgrave.jibs. 8490300

Lu, J. (2002). Intra- and inter-organization imitative behavior: institutional influences on Japanese firms' entry mode choice. Journal of International Business Studies, 33(1), 19-37. doi: 10.1057/palgrave.jibs.8491003

Macadar, B. (2009). A internacionalização de grandes empresas brasileiras e as experiências do Grupo Gerdau e da Marcopolo. Ensaios FEE, 30(1), 7-34.

Martin, X., Swaminathan, A., \& Mitchell, W. (1998). Organizational evolution in the interorganizational environment: incentives and constraints on international expansion strategy. Administrative Science Quarterly, 43(3), 566-601. doi: 10.2307/2393676

Meyer, J. W., \& Rowan, B. (1977). Institutionalized organizations: formal structure as myth and ceremony. American Journal of Sociology, 83(2), 340-363.

Meyer, K. E. (2001). Institutions, transaction costs, and entry mode choice in Eastern Europe. Journal of International Business Studies, 32(2), 357-367. doi: 10.1057/palgrave.jibs.8490957

Meyer, K. E., \& Peng, M. W. (2005). Probing theoretically into Central and Eastern Europe: transactions, resources, and institutions. Journal of International Business Studies, 36(6), 600621. doi: $10.1057 /$ palgrave.jibs. 8400167

Meyer, K. E., Estrin, S., Bhaymik, S. K., \& Peng, M. W. (2009). Institutions, resources and entry strategies in emerging economies. Strategic Management Journal, 30(1), 61-80. doi: $10.1002 / \mathrm{smj} .720$

Naiditch, S. (2007, outubro 4). Vinte e um anos de erros. Exame. Recuperado de http://exame.abril.com.br/revista-exame/edicoes/903/noticias/vinte-e-um-anos-de-errosm0139963 
North, D. (1990). Institutions, institutional change, and economic performance. New York, NY: Cambridge University Press.

Nunes, C. C. C., Serra, F. R., \& Ferreira, M. P. (2011). Internacionalização bancária brasileira: estudo de caso do banco Itaú. Revista Eletrônica Mestrado em Administração, 3(2), 57-74.

Oliver, C. (1991). Strategic responses to institutional processes. Academy of Management Review, 16(1), 145-179. doi: 10.5465/AMR.1991.4279002

Oliver, C. (1997). Sustainable competitive advantage: combining institutional and resource-based views. Strategic Management Journal, 18(9), 697-713. doi: 10.1002/(SICI)10970266(199710)18:9<697::AID-SMJ909>3.0.CO;2-C

Peng, M. W. (2003). Institutional transitions and strategic choices. Academy of Management Review, 28(2), 275-296. doi: 10.5465/AMR.2003.9416341

Peng, M. W., \& Heath, P. S. (1996). The growth of the firm in planned economies in transition: institutions, organizations, and strategic choices. Academy of Management Review, 21(2), 492528. doi: 10.5465/AMR.1996.9605060220

Peng, M. W., Wang, D. Y. L., \& Jiang, Y. (2008). An institution-based view of international business strategy: a focus on emerging economies. Journal of International Business Studies, 39(5), 920 936. doi: $10.1057 /$ palgrave.jibs. 8400377

Phillips, N., Tracey, P., \& Karra, N. (2009). Rethinking institutional distance: strengthening the tie between new institutional theory and international management. Strategic Organization, 7(3), 339-348. doi: 10.1177/1476127009337439

Ribeiro, F., \& Borini, F. (2010). Desinvestimento nos processos de internacionalização: o caso Petrobras. Revista de Administração em Diálogo, 12(2), 20-42.

Root, F. (1994). Entry strategies for international markets. New York, NY: Lexington Books.

Rosa, P. R. da, \& Rhoden, M. I. S. (2007). Internacionalização de uma empresa brasileira: um estudo de caso. Revista Eletrônica de Administração, 13(3), 684-704. Recuperado de http://seer.ufrgs.br/index.php/read/article/view/39990/25479

Rosenzweig, P., \& Singh, J. (1991). Organizational environments and the multinational enterprise. Academy of Management Review, 16(2), 340-361. doi: 10.5465/AMR.1991.4278953

Scherer, F. L., Gomes, C. M., \& Kruglianskas, I. (2009). The internationalization process of Brazilian companies: a study of multiple cases in the heavy construction industry. Brazilian Administration Review, 6(4), 280-298. Retrieved from http://www.scielo.br/pdf/bar/v6n4/v6n4a02.pdf. doi: $10.1590 / \mathrm{S} 1807-76922009000400002$

Scott, R. (2003). Organizations: rational, natural and open systems (5th ed.). Englewood Cliffs, NJ: Prentice Hall.

Serra, F., \& Ferreira, M. (2013). Oportunidade não é tudo. HSM Management, 98, 64-66.

Shenkar, O. (2001). Cultural distance revisited: towards a more rigorous conceptualization and measurement of cultural differences. Journal of International Business Studies, 32(3), 519-535. doi: $10.1057 /$ palgrave.jibs. 8490982

Simon, H. A. (1991). Bounded rationality and organizational learning. Organization Science, 2(1), 125134. doi. 10.1287 /orsc. 2.1 .125 
Stal, E. (2010). Internacionalização de empresas brasileiras e o papel da inovação na construção de vantagens competitivas. Revista de Administração e Inovação, 7(3), 120-149. doi: 10.5585/RAI.2010448

The Economist. (2010, November 25). Fiat plays double or quits with Chrisler. Retrieved from www.economist.com/node/17575017

Wachman, R. (2012, March 21). Jaguar-land rover and China's chery agree joint venture. The Guardian. Retrieved from http://www.theguardian.com/business/2012/mar/21/jaguar-land-rover-chinachery

Westney, E. (1993). Institutionalization theory and the multinational corporation. In S. Ghoshal \& E. Westney (Eds), Organization theory and the multinational corporation (pp. 53-76). New York, NY: St. Martin's Press.

Williamson, O. (1985). The economic institutions of capitalism: firms, markets, relational contracting. New York: Free Press.

Wright, M., Filatotchev, I., Hoskisson, R. E., \& Peng, M. W. (2005). Strategy research in emerging economies: challenging the conventional wisdom. Journal of Management Studies, 42(1), 1-33. doi: $10.1111 /$ j.1467-6486.2005.00487.x

Xu, D., \& Shenkar, O. (2002). Institutional distance and the multinational enterprise. Academy of Management Review, 27(4), 608-618. doi: 10.5465/AMR.2002.7566108

Zebinden, W., Oliva, F., \& Gaspar, M. (2007). A internacionalização da construtora Norberto Odebrecht. Revista de Ciências Empresariais da UNIPAR, 8(1/2), 87-106.

Zukin, S., \& DiMaggio, P. (1990). Structures of capital: the social organization of the economy. Cambridge: Cambridge University Press.

\section{Dados dos Autores}

Manuel Portugal Ferreira

Av. Francisco Matarazzo, 612, Prédio C, 05001-100, São Paulo, SP, Brasil. E-mail: manuel.portugal@ uninove.br

Fernando Ribeiro Serra

Av. Francisco Matarazzo, 612, Prédio C, 05001-100, São Paulo, SP, Brasil. E-mail: fernandoars@ uninove.br 